\title{
SJENICA, A NEWLY IDENTIFIED RADON PRIORITY AREA IN SERBIA, AND RADON DATA CORRELATED WITH GEOLOGICAL PARAMETERS USING THE MULTIPLE LINEAR REGRESSION MODEL
}

\author{
Zora S. ŽUNIĆ ${ }^{1}$, Zdenka STOJANOVSKA ${ }^{2}$, Blažo BOEV ${ }^{3}$, Ajka ŠORŠA ${ }^{4}$, Igor \\ ČELIKOVIĆ ${ }^{1}$, Zoran ĆURGUZ ${ }^{5}$, Tryggve RONNQUIST ${ }^{6}$, Aco JANIĆIJEVIĆ ${ }^{7}$ \\ \& Dragan ALAVANTIĆ ${ }^{1}$ \\ ${ }^{1}$ Vinča Institute of Nuclear Sciences, University of Belgrade, Belgrade, Serbia email:icelikovic@vin.bg.ac.rs \\ ${ }^{2}$ Faculty of Medical Sciences, Goce Delčev University, Štip, Republic of Macedonia \\ ${ }^{3}$ Faculty of Natural and Technical Sciences, Goce Delčev University, Štip, Republic of Macedonia \\ ${ }^{4}$ Croatian Geological Survey, Zagreb, Croatia \\ ${ }^{5}$ University of East Sarajevo, Faculty of Transport Doboj, Republic of Srpska, Bosnia and Herzegovina \\ ${ }^{6}$ Radonova, Box 6522, SE-751 38 UPPSALA, Sweden \\ ${ }^{7}$ Faculty of Technology and Metallurgy, University of Belgrade, Belgrade, Serbia
}

\begin{abstract}
The paper deals with the analysis of the annual indoor radon concentrations variations due to different geological parameters of Sjenica community, Western Serbia. The measured ${ }^{222} \mathrm{Rn}$ concentrations were ranging from 10 to $1130 \mathrm{~Bq} / \mathrm{m}^{3}$. In $14 \%$ of the buildings, the radon action level of $300 \mathrm{~Bq} / \mathrm{m}^{3}$ is exceeded, indicating that Sjenica community could be characterized as a radon priority area. Each of 35 measuring location was georeferenced and corresponding lithostratigraphic units and geological period was assigned. Data were analyzed using the multiple linear regression (MLR) method and two predictive models were developed. The MLR model generated by the geological periods explained $17 \%$ of the radon variability while, the better one, was the lithostratigraphic MLR model, which explained $52 \%$ of the radon variability. Analysis has shown that lithostratigraphic units are important parameters in the prediction of radon levels.
\end{abstract}

Keywords: Radon priority area; Sjenica; schools; geology; multiple linear regression

\section{INTRODUCTION}

Radon is radioactive gas, and its most important isotope ${ }^{222} \mathrm{Rn}$ (in text denoted as $\mathrm{Rn}$ or radon if not otherwise stated) is a decay product of radium $\left({ }^{226} \mathrm{Ra}\right)$ in the uranium $\left({ }^{238} \mathrm{U}\right)$ chain, present in different concentrations in all terrestrial materials. After emanation from mineral grains, radon is transported by means of diffusion and advection reaching the atmosphere or can get accumulated in enclosed spaces. Under some circumstances, the radon concentration in the indoor environment can reach a high level. The indoor radon concentration is considered as health risk (WHO, 2009) and thus it is becoming a subject of radiation protection regulations. In Europe, radon is regulated by the European Council directives laying down basic safety standards (BSS) for "protection against the dangers arising from exposure to ionizing radiation" (EC, 2014). Among others, the BSS requires: (1) establishing reference levels for long-term indoor $\mathrm{Rn}$ concentration, not exceeding $300 \mathrm{~Bq} / \mathrm{m}^{3}$ for both dwellings and workplaces and (2) development of a national radon action plan. According to article 103(3) from EU's BSS radon priority area (RPA) is defined as: an area where annual radon concentration in a significant number of buildings is expected to exceed national reference level (EC, 2014). Due to this vague RPA definition, there are different threshold values considered in each country. Most countries in EU defined radon priority area in their national legislation as an area wherein more than $10 \%$ of the residential buildings, the reference level of $300 \mathrm{~Bq} / \mathrm{m}^{3}$ is exceeded. Since in 
Serbia there is still no regulation regarding the definition of RPA, we will refer to the most commonly used international one.

The pathway from radon generation in a terrestrial material (soil, rocks and building materials) to its indoor accumulation is complex and depends on numerous factors, resulting in a large temporal and spatial variability of indoor radon. In general, the factors influencing indoor radon concentrations are classified into three categories which are related to:

1) geochemical and geological characteristics of local and regional soils and rocks having different ${ }^{226} \mathrm{Ra}$ concentration;

2) environmental conditions that are responsible for radon emanation and radon transport through soil that include: grain size, water content, porosity; as well as rock thickness, permeability and the existence of faults and karsts. In the shallow environment, meteorological parameters become important;

3) building characteristics that include the type of building material, cracks in foundation and walls, ventilation rate (Ciotoli et al., 2017).

Therefore, it is not a surprise that, numerous scientific studies appeared in the literature trying to solve such a difficult issue using different analytical techniques (among others, Zunic et al., 2017a, 2017b; Ciotoli et al., 2017; Ivanova et al., 2017; Yarmoshenko et al., 2016; Kropat et al, 2015; Bossew et al., 2014; Bochicchio et al., 2014; Carpentieri et al., 2011). Generally, two approaches are encountered. The univariate analysis considers the impact of each factor on $\mathrm{Rn}$ variation separately. The multivariate analysis considers the impact of several factors simultaneously. The main goal of each analytical technique is to explain and predict Rn variations with high accuracy. Consequently, prediction of RPA would allow local authorities to develop an adequate radon program. The statistical modelling techniques have included parametric or nonparametric methodologies but finding the ideal model that would explain the $\mathrm{Rn}$ variations is still a challenge. The purpose of the developed models is a prediction at unsampled locations and it can serve for optimizing and prioritizing the allocation of resources, in terms of denser surveys, prevention and mitigation of $\mathrm{Rn}$ exposure.

The municipality of Sjenica is placed on the tectonic unit of Dinaric Alps developed during the same geological period of Alpine build-up. Because the tectonic activity is still active in this area, especially along the faults, it is interesting to investigate this region. One of the main characteristics of the region are karsts created by the water erosion of the soluble rocks such as dolomites and limestones. These geological features favour radon transport toward the shallow environment. In addition, this region is one of the coldest in Europe in winter, with the winter average of $-2.9{ }^{\circ} \mathrm{C}$ (Šabić \& Pavlović, 2004), causing the reduction in ventilation rate during the winter period, which also contributes to the build-up of radon in dwellings.

The municipality of Sjenica covering an area of $1059 \mathrm{~km}^{2}$, is located at high altitude ( $\left.h=1026 \mathrm{~m}\right)$ in the southwestern part of Serbia (insert of Figure 1). This is the largest municipality in Serbia, with 107 settlements over 12 entities and around 27000 inhabitants (Census, 2011).

Indoor radon concentrations were measured in 35 locations in the region of Sjenica. To estimate to what extent indoor $\mathrm{Rn}$ concentrations can be explained and predicted by lithostratigraphic units and geological period, the multiple linear regression (MLR) analysis was used.

\section{MATERIAL AND METHODS}

\subsection{Indoor radon concentrations measurements}

The long-term radon concentration was measured using a CR-39 detector, positioned in the bottom of a cylindrical diffusion chamber (dimensions $\emptyset 58 \mathrm{~mm}$, height $20 \mathrm{~mm}$ ) commercially named Gamma 1, provided and analysed by Landauer Company, Sweden. This type of detector was used in other studies so far (Stojanovska et al., 2016; 2014; Ćurguz et al., 2015). The relative expanded combined uncertainty, given at 95\% confidence level was in an interval from $16 \%$ up to $40 \%$ for $\mathrm{Rn}$ value close to the detection limit.

The indoor Rn measurements were performed in 35 occupied ground floor rooms of public buildings: schools, kindergarten and meteorological station of Sjenica. We assumed that spatial scattering of public buildings throughout the municipality territory allows them to be representative for the whole area (Zunic et al., 2017a). Inside a room, the detectors were deployed on the wall far from the doors, windows and heating source as well. In these positions, the detectors were exposed for 12 months, starting with the first week of November 2014 and ending on the first week of November 2015.

\subsection{Geological characterization of the locations}

Geology of the investigated area is described by four sheets of the Basic geological map of SFRY, 1:100000 (Brković et al., 1976a; 1976b; Ćirić et al., 1978; Ćirić 1980; Mojsilović et al., 1978; 1980; 
Živaljević et al., 1983; 1984) and the sheet of the Geological map SFR Yugoslavia, scale 1:500000 (Sikošek, 1971; Veselinović \& Vuković, 1970). Locations of the measurement points are shown in Figure 1. Corresponding geological period and lithostratigraphic units are ascribed for each measuring location. In Table 1 a summary of the geological classification is given.

Although a relatively small area was under investigation, the measuring locations are characterized by different lithostratigraphy which originates from different geological periods (Fig. 1 and Table 1). The observed locations were diverse within 10 lithostratigraphic units and 5 geological periods.

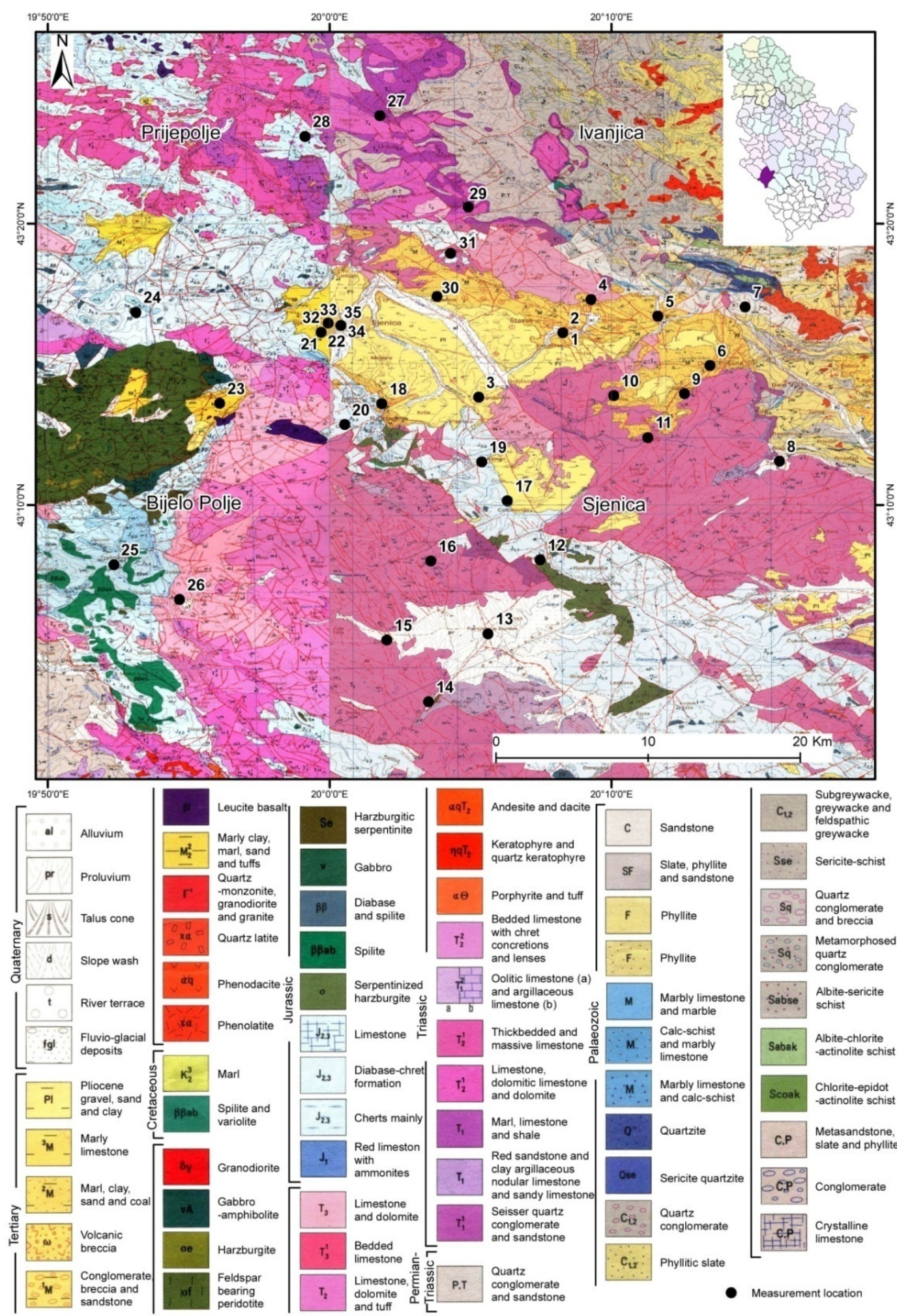

Figure 1. Geology of Sjenica community with 35 measuring locations. Insert shows location of community of Sjenica. (Brković et al., 1976a; 1976b; Ćirić at al., 1978; Ćirić 1980; Mojsilović at al., 1978; 1980; Živaljević et al., 1983; 1984) 
Table 1. Geological information of the buildings sites

\begin{tabular}{|l|l|c|c|l|l|r|}
\hline Geological period & & Frequency & $(\%)$ & Lithostratigraphic units & Frequency & (\%) \\
\hline Jurassic & & 7 & 20 & Diabase and spilite & 3 & 9 \\
\hline & & & & Cherts mainly & 4 & 11 \\
\hline Paleozoic & & 1 & 3 & Sandstone & 1 & 3 \\
\hline Quaternary & & 2 & 6 & Prolovium & 2 & 6 \\
\hline Tertiary & & 16 & 46 & Conglomerate breccia and sandstone & 3 & 9 \\
\hline & & & & Marl,clay, sand and coal & 3 & 9 \\
\hline & & & & Marly, limestone & 3 & 9 \\
\hline & & & & Pliocene gravel, sand and clay & 7 & 20 \\
\hline Triassic & & 9 & 26 & Limestone and dolomite & 3 \\
\hline
\end{tabular}

\subsection{Multiple linear regression}

For analyses of the geological parameters simultaneously effect on the indoor radon concentrations variations, a stepwise forward multiple linear regression (MLR) was applied on lntransformed data.

Generally, the MLR method is involved on determining whether a particular explanatory variable, has a significant effect on a depended variable (ln $\mathrm{Rn}$ in our case) after adjusting for the effects of the other explanatory variables (geological parameters). Moreover, it is possible to assess the combined effect of these $n$ geological parameters on $\ln \mathrm{Rn}$, by formulating an appropriate model which can then be used to predict values of $\ln \mathrm{Rn}$ for a particular combination of geological parameters. Mathematically, the MLR model is written as follows:

$(\ln R n)_{\mathrm{p}}=(\ln \mathrm{Rn})_{\mathrm{pAV}}+a_{1} \mathrm{G}_{\mathrm{P} 1}+a_{2} \mathrm{G}_{\mathrm{P} 2}+\ldots+a_{\mathrm{n}} \mathrm{G}_{\mathrm{Pn}}$

Where:

$(\ln \mathrm{Rn})_{\mathrm{p}}$ is predicted value for a particular set of values of geological parameters: $\mathrm{G}_{\mathrm{P} 1}, \mathrm{G}_{\mathrm{P} 2} \ldots . . . \mathrm{G}_{\mathrm{p}}$;

(ln $\mathrm{Rn})_{\mathrm{PAV}}$ is intercept of the model, the value is constant, $(\operatorname{lnRn})_{\mathrm{p}}=(\operatorname{lnRn})_{\mathrm{av}}$ when all the $\mathrm{G}_{\mathrm{p}}=0$;

$a_{1}, \quad a_{2}, \ldots, \quad a_{\mathrm{n}}$ are estimated regression coefficients, each one quantifying the average change in $(\ln R n)_{p}$ due to certain $G_{p}$, adjusting for all the other Gp.

Because of multicollinearity between geological periods and lithostratigraphy, two models were generated to analyze radon dependence to each of them separately. Model (1) uses categorises in geological periods, while model (2) uses categories of the lithostratigraphic units.

The basic assumption in MLR modelling is that the variances are homogeneous and that the residuals of the model are identically distributed. For both models, requirements for fitting criteria: normal distribution and homoscedasticity of the residuals was tested.

The analysis was done using the Xlstat statistical software for Excel at 95\% confidence level.

\section{RESULTS AND DISCUSSION}

\subsection{Data characterization}

The basic description of Rn data is shown in Figure 2 and Table 2. Figure 2 indicates that the distribution of measured indoor radon concentrations is well approximated by the log-normal function. The null hypothesis was also confirmed by the Kolmogorov-Smirnov and $\chi^{2}$ tests $(\mathrm{p}>0.05)$.
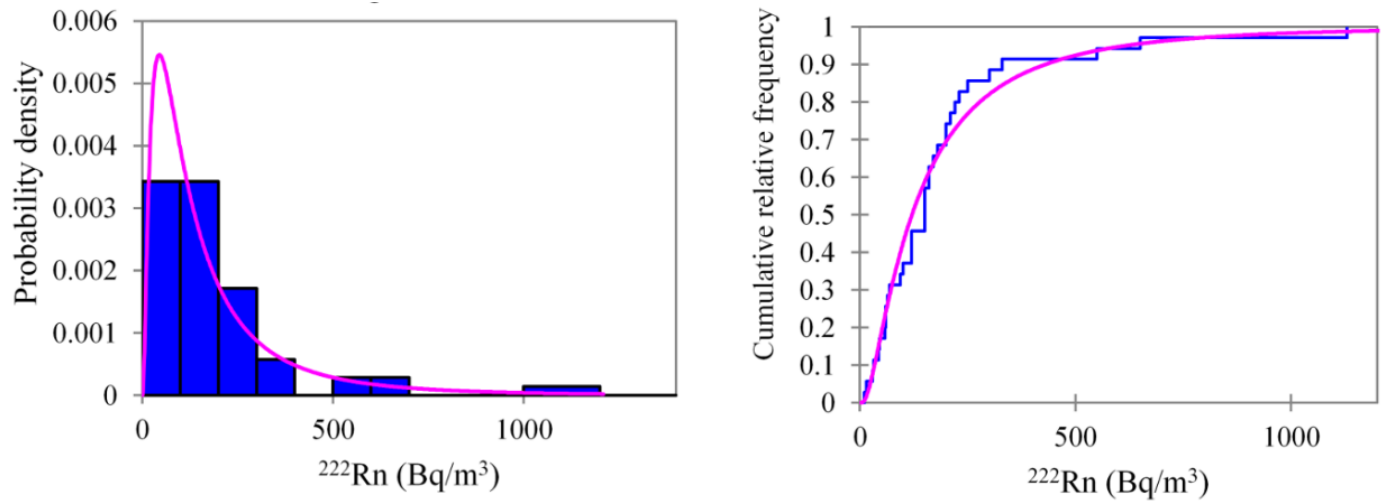

Figure 2. Histograms (left) and cumulative distributions (right) of measured ${ }^{222} \mathrm{Rn}$ (blue line) and modelled with lognormal function (pink line) with parameters $\mu=4.7922, \sigma=0.9910$. 
Since we have assumed that our measurements are representative for the entire community, from the log-normal model in Figure 2 can be concluded that in Sjenica region: (1) Rn concentrations lower than $100 \mathrm{~Bq} / \mathrm{m}^{3}$ are most probable; (2) Rn concentration higher than the action level of $300 \mathrm{~Bq} / \mathrm{m}^{3}$ could occur in $14 \%$ of the buildings. According to the most common definition of RPA in EU countries, the results indicate that the investigated area is a radon priority area.

Table 2. Descriptive statistic of measured indoor radon concentrations (Rn)

\begin{tabular}{|l|r|}
\hline \multicolumn{1}{|c|}{ Statistic } & Rn \\
\hline No. of observations & 35 \\
\hline Minimum $\left(\mathrm{Bq} / \mathrm{m}^{3}\right)$ & 10 \\
\hline Maximum $\left(\mathrm{Bq} / \mathrm{m}^{3}\right)$ & 1130 \\
\hline 1st Quartile $\left(\mathrm{Bq} / \mathrm{m}^{3}\right)$ & 62 \\
\hline Median $\left(\mathrm{Bq} / \mathrm{m}^{3}\right)$ & 150 \\
\hline 3rd Quartile $\left(\mathrm{Bq} / \mathrm{m}^{3}\right)$ & 205 \\
\hline Arithmetic mean $(\mathrm{AM})\left(\mathrm{Bq} / \mathrm{m}^{3}\right)$ & 188 \\
\hline Standard deviation $(\mathrm{SD})\left(\mathrm{Bq} / \mathrm{m}^{3}\right)$ & 213 \\
\hline Geometric mean $(\mathrm{GM})\left(\mathrm{Bq} / \mathrm{m}^{3}\right)$ & 121 \\
\hline Geometric standard deviation $(\mathrm{GSD})$ & 2.69 \\
\hline
\end{tabular}

Because of data log-normality, GM and GSD were used as a measure of central tendency and dispersion of the $\mathrm{Rn}$ results, respectively. The GM of $121 \mathrm{~Bq} / \mathrm{m}^{3}$, representing the mean value of $\mathrm{Rn}$ in the investigated area (Table 2), is higher than the reported GM values in most of the previous studies in different but also small regions in Serbia as well as in the Balkan Peninsula. For example, it is higher when compared to the previously published GM value of $97 \mathrm{~Bq} / \mathrm{m}^{3}$ for $\mathrm{Rn}$, measured in 207 schools in 7 communities of Southern Serbia, (Zunic et al., 2013). The GM value is also higher than the value of $99 \mathrm{~Bq} / \mathrm{m}^{3}$ reported for 25 schools in Banja Luka (Republic of Srpska), (Curguz et al., 2015), than $\mathrm{GM}=76 \mathrm{~Bq} / \mathrm{m}^{3}$ obtained for the schools in 4 municipalities of Macedonia, (Stojanovska et al., 2014) and slightly higher than $\mathrm{GM}=101 \mathrm{~Bq} / \mathrm{m}^{3}$ measured in the kindergartens of Sofia city (Bulgaria) (Ivanova et al., 2014). In some surveys from the Balkan Peninsula, GM has revealed higher measured $\mathrm{Rn}$ values, in comparison with the investigated indoor radon concentrations of public buildings of Sjenica community. The highest GM value of $529 \mathrm{~Bq} / \mathrm{m}^{3}$ was reported in the study performed in dwellings of Niška Banja, South Serbia (Zunic et al., 2007; Zunic et al., 2014), where the main source of radon is the radium enriched travertine formation on which the region is partly located (Žunic et al., 2007). Another high GM of $477 \mathrm{~Bq} / \mathrm{m}^{3}$, related to the uranium deposition, was reported for Gornja Stubla in Kosovo (Zunic et al., 2001). Thus, Gornja Stubla at Kosovo and Niška Banja at Southern Serbia are two identified high natural radiation areas (Zunic et al., 2009, Zunic, 2010). A high $\mathrm{GM}=220 \mathrm{~Bq} / \mathrm{m}^{3}$ indoor radon concentration, associated with ${ }^{238} \mathrm{U}$ deposits, was also obtained in a Bulgarian survey performed in the kindergartens (Vuchkov et al., 2013) and schools of the Kremikovtsi municipality, and in Kratovsko Zletovska volcanic area in Macedonia, where a $\mathrm{GM}=157 \mathrm{~Bq} / \mathrm{m}^{3}$ was reported for schools and dwellings (Stojanovska et al. 2016). Initial research in this region started in Slovenia (Vaupotic et al., 1992, Vaupotic et al., 1993, Vaupotic et al., 2000).

To analyze the relation between $\mathrm{Rn}$ and geology, its concentrations were grouped consistently with geological parameters: geological period (4 categories) and Lithostratiology (9 categories). The category with only one measurement, sandstone from the Palaeozoic geological period, was not included in the analysis. The basic statistic of data is given in Table 3 .

From Table 3, the lowest GM indoor radon $\mathrm{Rn}$ concentrations appeared for the Jurassic geological period. The tertiary geological period is characterized by the highest GM of indoor radon concentration, where also the highest single radon concentration was identified.

Table 3. Basic statistic of indoor radon concentrations grouped according to geological parameters

\begin{tabular}{|c|c|c|c|c|c|c|c|c|c|}
\hline \multirow{2}{*}{$\begin{array}{l}\text { Geological } \\
\text { period }\end{array}$} & \multicolumn{4}{|c|}{$\mathrm{Rn}\left(\mathrm{Bq} / \mathrm{m}^{3}\right)$} & \multirow{2}{*}{ Lithostratigraphic units } & \multicolumn{4}{|c|}{$\mathrm{Rn}\left(\mathrm{Bq} / \mathrm{m}^{3}\right)$} \\
\hline & Min & Max & GM & GSD* & & Min & Max & GM & GSD* \\
\hline \multirow[t]{2}{*}{ Jurassic } & 15 & 180 & 56 & 2.30 & Diabase and spilite & 29 & 120 & 54 & 2.07 \\
\hline & & & & & Cherts mainly & 15 & 180 & 57 & 2.77 \\
\hline Quaternary & 150 & 160 & 155 & 1.05 & Prolovium & 150 & 160 & 155 & 1.05 \\
\hline \multirow[t]{4}{*}{ Tertiary } & 44 & 1130 & 188 & 2.37 & $\begin{array}{l}\text { Conglomerate, breccia and } \\
\text { sandstone }\end{array}$ & 230 & 1130 & 553 & 2.24 \\
\hline & & & & & Marl, clay, sand and coal & 120 & 200 & 160 & 1.30 \\
\hline & & & & & Marly, limestone & 69 & 550 & 225 & 2.91 \\
\hline & & & & & Pliocene gravel, sand and clay & 44 & 210 & 117 & 1.82 \\
\hline \multirow[t]{2}{*}{ Triassic } & 10 & 330 & 88 & 2.92 & Limestone and dolomite & 10 & 58 & 26 & 2.45 \\
\hline & & & & & Limestone, dolomite and tuff & 94 & 330 & 159 & 1.61 \\
\hline
\end{tabular}


According to lithostratigraphy, the highest GM was obtained on conglomerate, breccia and sandstone from Tertiary period. The explanations are the following: (1) Conglomerate and breccia are clastic sedimentary rocks, formed from different types of rock fragments. Some of those fragments may be of volcanic origin known to have high concentrations of uranium $\left({ }^{238} \mathrm{U}\right)$ and thorium $\left({ }^{232} \mathrm{Th}\right) .(2)$ Sandstones are also clastic sedimentary rock built from smaller fragments in comparison to conglomerate and breccia. Their composition may be very heterogeneous, containing grains of zircon and apatite whose chemical composition could have an elevated concentration of ${ }^{238} \mathrm{U}$ and ${ }^{232} \mathrm{Th}$. Common to all of them is high porosity, enabling an easy movement of radon generated in greater depths, its exhalation from the soil surface and finally its accumulation in the buildings while reaching high concentrations.

On the contrary, lower GM of Rn values are related to diabase, spilite and cherts and to the Triassic Limestone and dolomite. Volcanic part of the lithological sequence is represented by diabase and spilite which were poured on the ocean ground during their formation. Hydrothermal alterations that are happening due to seawater and magma interaction lead to a change of mineral content resulting in the absence of minerals in diabase and spilite that would bring uranium.

\subsection{Models generation}

Before model generation was started, the test for normality, homogeneity and ANOVA analysis of variance were done. The results were:

(1) In-transformed $\mathrm{Rn}$ data followed the normal distribution ( $\chi^{2}$ tests, $p=0.61>0.05$ );

(2) the Rn data had the same variance within the groups (Bartlett test for the geological period, $p=0.18>0.05$; Bartlett test for lithostratigraphy, $p=0.34>0.05$ );

(3) the effects of the geological period and lithostratigraphy on the indoor radon concentrations variation were statistically significant (ANOVA for the geological period, $p=0.03<0.05$; ANOVA for lithostratigraphy, $p=0.001<0.05$ ).

The ANOVA results indicated that at least one of the variables related to the geological period as well as to lithostratigraphy is independently associated with the Rn variation. To establish which of them is a significant predictor of Rn, MLR was applied and two linear models were developed.

The stepwise forward selection process for a MLR model generation starts by adding the geological parameters ( $G_{p}$ in equation 1) with the largest contribution $\left(\mathrm{G}_{\mathrm{P} 1}\right)$ (the criterion used was Student's $t$ statistic). If a second parameter $\left(\mathrm{G}_{\mathrm{P} 2}\right)$ is such that the probability associated with its $t$ is less than the probability $(p)$ for entry, it was added to the model. The same procedure was for all parameters, until no more parameters could be added.

The MLR outputs: intercept, regression coefficients with its standard errors (SE), $t$-test values with corresponding error probabilities $(p)$ and confidence intervals for both models are given in Table 4.

Table 4. Multiple regression model parameters: indoor radon concentrations and geological parameters dependence

\begin{tabular}{|c|c|c|c|c|c|c|c|}
\hline \multicolumn{2}{|c|}{ Models parameters $\left(\mathrm{G}_{\mathrm{P}}\right)$} & $\begin{array}{l}\text { Regression } \\
\text { coefficient }\end{array}$ & $\begin{array}{c}\mathrm{SE} \\
\left(\mathrm{Bq} / \mathrm{m}^{3}\right)\end{array}$ & $\mathrm{t}$ & $p>|t|$ & $\begin{array}{l}\text { Lower } \\
\text { bound }\end{array}$ & $\begin{array}{l}\text { Upper } \\
\text { bound }\end{array}$ \\
\hline \multirow{5}{*}{ 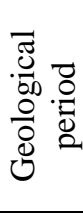 } & Intercept & 4.36 & 0.21 & 20.38 & $<0.0001$ & 3.92 & 4.79 \\
\hline & Jurassic & 0.00 & 0.00 & & & & \\
\hline & Quaternary & 0.00 & 0.00 & & & & \\
\hline & Tertiary & 0.88 & 0.31 & 2.81 & 0.01 & 0.24 & 1.51 \\
\hline & Triassic & 0.00 & 0.00 & & & & \\
\hline \multirow{10}{*}{ 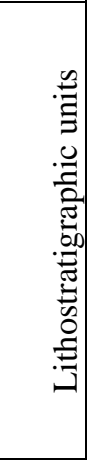 } & Intercept & 5.01 & 0.15 & 33.37 & $<0.0001$ & 4.71 & 5.32 \\
\hline & Cherts mainly & -0.98 & 0.38 & -2.60 & 0.01 & -1.74 & -0.21 \\
\hline & $\begin{array}{l}\text { Conglomerate breccia and } \\
\text { sandstone }\end{array}$ & 1.30 & 0.43 & 3.06 & 0.00 & 0.43 & 2.17 \\
\hline & Diabase and spilite & -1.03 & 0.43 & -2.42 & 0.02 & -1.90 & -0.16 \\
\hline & Limestone and dolomite & -1.74 & 0.43 & -4.09 & 0.00 & -2.61 & -0.87 \\
\hline & Limestone, dolomite and tuff & 0.00 & 0.00 & & & & \\
\hline & Marl,clay, sand and coal & 0.00 & 0.00 & & & & \\
\hline & Marly, limestone & 0.00 & 0.00 & & & & \\
\hline & Pliocene gravel, sand and clay & 0.00 & 0.00 & & & & \\
\hline & Prolovium & 0.00 & 0.00 & & & & \\
\hline
\end{tabular}


Incorporating the significant coefficients from Table 4 into an equation (1), gives models for: geological period:

$(\ln \mathrm{Rn})_{\mathrm{p}}=4.36+0.88$ Tertiary

lithostratigraphic units:

$(\ln \mathrm{Rn})_{\mathrm{p}}=5.01-1.74$ Limestone and dolomite -

-1.03Diabase and spilite -0.98 Cherts mainly +

+1.30 Conglomerate breccia and sandstone

The regression coefficients that are significantly different from zero, and therefore judged to be important independent predictors of indoor radon concentration in the observed region, are: (1) Tertiary geological period (having a higher Rn than the mean $\mathrm{Rn}$ of other geological periods); (2) Conglomerate breccia and sandstone (having a $\mathrm{Rn}$ higher values than the mean $\mathrm{Rn}$ concentration in other lithostratigraphic units) and Cherts mainly, Diabase and spilite, Limestone and dolomite (having a lower values than the mean $\mathrm{Rn}$ ).

The reason for a higher $\mathrm{Rn}$ associated with the Tertiary period is directly related to lithostratigraphic units originating from that period.

\subsection{Models evaluation}

An evaluation of the MLR model is an important part of the analysis to ensure that the proposed model is valid and to determine its level of accuracy. Table 5 shows the results of these analyses considering both models. The first part is related to the analysis of residuals, whereas the residual for each individual result is the difference between measured $\ln$ $\mathrm{Rn}$ value and the corresponding predicted $(\ln \mathrm{Rn})_{\mathrm{P}}$ value, obtained from the model. For both models, the residuals appeared normally distributed without obvious patterns. Heteroscedasticity testing confirmed the assumption of constant error variance for both models (the first two rows in Table 5).

To quantify the accuracy of the Rn models, adjusted coefficient of determination (adjusted $\mathrm{R}^{2}$ ) and root mean square error (RMSE) was used. Adjusted $\mathrm{R}^{2}$ defines to what extent the regression model can explain variation in the dependent variable adjusted by the number of predictors, while RMSE is a measure of model error. A large value of $\mathrm{R}^{2}$ and a small value for RMSE suggests that the model is a good fit for the measured data.

In our case, the predictive performance of the MLR model generated using the geological periods can be considered low, since $\mathrm{R}^{2}=0.17$ and RMSE $=0.91$. Such a performance highlights the limitation in explaining the $\mathrm{Rn}$ variations. On the other hand, the second model, where the lithostratigraphic units were used as the predictor variables, gives adjusted $\mathrm{R}^{2}=0.52$ and RMSE $=0.69$. These results indicate that lithostratigraphy is explaining to a better extent geological radon variation. Approximately one half of the $\mathrm{Rn}$ variability is explained as a linear relationship between $\mathrm{Rn}$ and the lithostratigraphic units included in the model. Due to numerous factors affecting radon variation, such as (hydro)geological parameters, the proximity of faults, building characteristics, living habits that were not included in the model, it is surprising that only around $48 \%$ of $\mathrm{Rn}$ variation could not be explained by the model.

The lithostratigraphic model's performance generated in this work, in general, is higher than those found in the literature. For example, from the MLR analysis of 9 building factors for 963 Greek dwellings has generated a model that could predict only $2.9 \%$ of the Rn variability. (Nikolopoulos et al., 2014). Also, linear modelling was applied in a Rn study performed in 334 primary schools of 13 municipalities of Southern Serbia. The considered independent variables: village/town, group of a municipality and floor were explaining $26 \%$ of variability (Bochicchio et al., 2014). Radon relation with building and lithology components in 721 Italian rooms was modelled with an accuracy of $\mathrm{R}^{2}=53 \%$ (Borgoni et al., 2014). Ivanova et al., (2017) have shown by applying the nonparametric Lowess and artificial neural network methods for $\mathrm{Rn}$ modelling, that model performance is a function of the geology and geographical position of the area where the measurements were done.

For further evaluation of the models, individual differences between the measured and predicted Rn concentrations were examined. For each predicted $(\ln \mathrm{Rn})_{\mathrm{p}}$ value, the corresponding relative deviation $(\delta)$ from the measured $(\operatorname{lnRn})_{\mathrm{m}}$ was calculated:

Table 5. Models evaluation

\begin{tabular}{|l|l|l|l|}
\hline Model & & Geological periods & Lithostratigraphy \\
\hline \multirow{2}{*}{$\begin{array}{l}\text { Validation of the } \\
\text { model }\end{array}$} & Normality of residuals $\chi^{2}$ test & $p=0.67>0.05$ & $p=0.79>0.05$ \\
\cline { 2 - 4 } & $\begin{array}{l}\text { Heteroscedasticity of differences } \\
\text { Bartlett test }\end{array}$ & $p=0.18>0.05$ & $p=0.34>0.05$ \\
\hline \multirow{2}{*}{ Goodness of fit } & $\mathrm{R}^{2}$ & 0.17 & 0.52 \\
\cline { 2 - 4 } & RMSE & 0.91 & 0.47 \\
\hline
\end{tabular}


$\delta=\frac{(\ln \mathrm{Rn})_{\mathrm{m}}-(\ln \mathrm{Rn})_{\mathrm{p}}}{(\ln \mathrm{Rn})_{\mathrm{m}}} 100 \%$

The analysis showed that the $\delta$ of the predicted $\mathrm{Rn}$ concentration against the measured $\mathrm{Rn}$ concentration was in a range from $-89 \%$ to $26 \%$ for the Geological period model and from $-49 \%$ to $22 \%$ for the lithostratigraphic model. This agrees with the model's performance, where the relative deviation is lower for the second model. Of course, the reduced quality of the models and thus the relatively large deviation is because it does not include all factors significantly affecting Rn concentration. In our case, as already mentioned, the characteristics of buildings and living habits were not included in the analysis. Indoor radon measurement uncertainty was also not taken into consideration. For both models, the relative deviations $(\delta)$ against the relative combined uncertainties $(u)$ are plotted in Figure 3. It can be noticed that the most common values of the $\delta$ for both models are ranging from 0 to 20\% which corresponds to an $u$ in the range of 10 to $20 \%$. The two extreme $(\delta)$ and $(u)$ values concerning the measured Rn concentration are close to the detection limit. Comparing the $\delta$ and $u$ for each pair of results, we got that in 14 of 34 cases for the Geological period model and in 10 of 34 cases for the lithostratigraphic model, $\delta>u$. Unfortunately, due to the small number of results, further analysis for measuring uncertainty impact on the quality of prediction model was not possible. However, in this case, an indication of its possible influence is obtained as well as an idea for further research in this direction.

\section{CONCLUSION}

The annual indoor radon concentrations were evaluated for public buildings throughout Sjenica municipality (Serbia). Rn concentrations higher than the action level of $300 \mathrm{~Bq} / \mathrm{m}^{3}$ were observed for $14 \%$ of the buildings. The highest measured Rn concentration was $1130 \mathrm{~Bq} / \mathrm{m}^{3}$. According to the definition of RPA, as an area where more than $10 \%$ of the dwellings are exceeding the reference level of 300 $\mathrm{Bq} / \mathrm{m}^{3}$, the municipality of Sjenica could be identified as new radon priority area in Serbia.

The results of this investigation highlights that it is possible to predict indoor radon concentrations using the geological data to an acceptable level of accuracy with a limited number of measurements.

Two MLR empirical models were generated for $\mathrm{Rn}$ prediction due to geological parameters. The performance of the models has been evaluated based on two criteria, i.e., $\mathrm{R}^{2}$ and RMSE. It was found that that the capability of the lithostratigraphic model $\left(\mathrm{R}^{2}=0.52\right.$, RMSE $\left.=0.47\right)$ is slightly higher than the developed model for the $\mathrm{Rn}$ prediction due to the geological period $\left(\mathrm{R}^{2}=0.17\right.$, RMSE $\left.=0.91\right)$. Comparing the relative value of the model's residuals $(\delta)$ and relative combined uncertainty of the measurements $(u)$ for each pair of results, it was found that in more cases $\delta<u$. This indicates that before making a conclusion about the quality of the model, the measurement uncertainty should also be considered.

For the practical implementation of the models proposed in this study by a regulatory authority, this finding has a positive impact. It is important to note that the models are useful for drawing general conclusions about the occurrence of indoor radon in specific lithostratigraphic units, but the predicted $\mathrm{Rn}$ concentrations are not proposed to be used in predicting individual concentrations at specific building sites nor as a decision-making tool for property owners to decide whether to test for $\mathrm{Rn}$ at specific locations.

For future research, the MRA should be extended to include other parameters that could influence the increase of radon concentrations in the indoor environment.
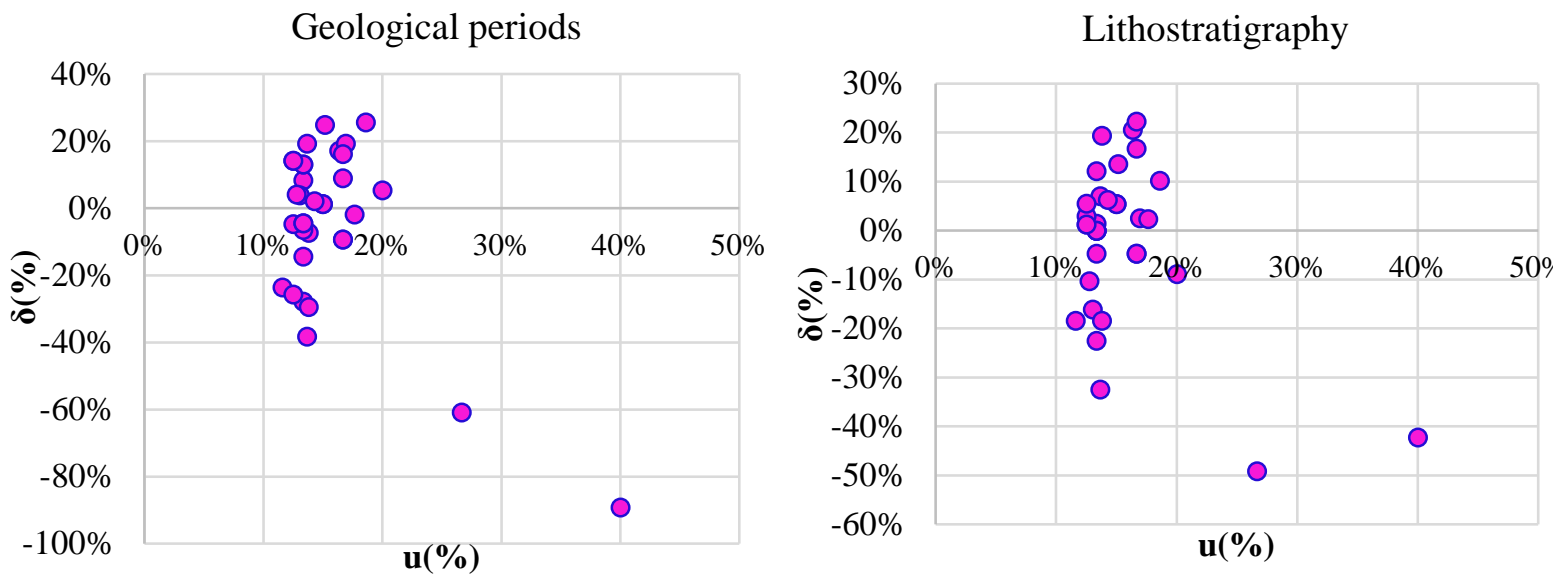

Figure 3. Relative residuals $\delta$ generated from both models against relative combined uncertainty of measured radon concentration $u$. 


\section{Acknowledgment}

The financial support of the Ministry for Education, Science and Technological Development of the Republic of Serbia under the Projects III 41028 and OI171018 is highly appreciated. We are very grateful for the help in conducting field campaign around Sjenica community to $\mathrm{Mr}$ Fadil Mahmutovic, director of the hydrometeorological station, and particularly for the generous collaboration for the realization of the fieldwork itself to Mr Hazbo Mujovic, president of Sjenica community, and to all members of his team, to the directors of all schools and particularly to the drivers for safe car driving. Special thanks go to the pupils of all schools who, in the best manner, took care of the deployed detectors.

\section{REFERENCES}

Bochicchio, F., Žunić, Z. S., Carpentieri, C., Antignani, S., Venoso, G., Carelli, V., Cordedda, C., Veselinović, N., Tollefsen, T., Bossew, P., 2014. Radon in indoor air of primary schools: A systematic survey to evaluate factors affecting radon concentration levels and their variability. Indoor Air. 24, 3, 315-326.

Borgoni, R., De Francesco, D., De Bartolo, D., Tzavidis, N., 2014. Hierarchical modelling of indoor radon concentration: how much do geology and building factors matter? J. Environ. Radioact. 138, 227-237.

Bossew, P., Zunic, Z. S., Stojanovska, Z., Tollefsen, T., Carpentieri, C., Veselinovic, N., Komatina, S., Vaupotic, J., Simovic, D., Antignanie, S., \& Bochicchio, F., 2014. Geographical distribution of the annual mean radon concentrations, in primary schools of Southern Serbia -application of geostatistical methods. J. Environ. Radioact. 127, 141-148.

Brković, T., Malešević, M., Urošević, M., Trifunović, S., Radovanović Z., 1976a. Osnovna geološka karta SFRJ 1:100000, list Ivanjica K34-17 [Basic geological map of SFRY 1:100000, Ivanjica sheet in Serbian]. Savezni geološki zavod, Beograd.

Brković, T., Malešević, M., Urošević, M., Trifunović, S., Radovanović, Z., Dimitrijević, M., Dimitrijević, M. N., 1976b. Osnovna geološka karta SFRJ 1:100000. Tumač za list Ivanjica K34-17 [Basic geological map of SFRY 1:100000, Geology of the Ivanjica sheet - in Serbian].- Savezni geološki zavod, Beograd.

Carpentieri, C., Zunic, Z. S., Carelli, V., Cordedda, C., Ferrigno, G., Veselinovic, N., Bossew, P., Tollefsen, T., Cuknic, O., Vojinovic, Z., Bochicchio, F., 2011. Assessment of long-term radon concentration measurement precision in field conditions (Serbian schools) for a survey carried out by an international collaboration. Radiat. Prot. Dosim. 145, 2-3, 305-311.

Census, 2011. 2011 Census of Population, Households and Dwellings in the Republic of Serbia, ISBN 978-866161-028-8

Ciotoli G., Voltaggio, M., Tuccimei, P., Soligo, M., Pasculli, A., Beaubien, S. E. \& Bigi, S., 2017. Geographically weighted regression and geostatistical techniques to construct the geogenic radon potential map of the Lazio region: A methodological proposal for the European Atlas of Natural Radiation, Journal of Environmental Radioactivity 166 (2017) 355-375.

Ćirić, A. M., 1980. Osnovna geološka karta SFRJ 1:100000. Tumač za list Prijepolje K34-16 [Basic geological map of SFRY 1:100000, Geology of the Prijepolje sheet - in Serbian]. Savezni geološki zavod, Beograd.

Ćirić, A. M., Obradović, Z., Novković, D., Popović, A., Kraičić, Lj. Jović, B. J., Serdar, R., 1978. Osnovna geološka karta SFRJ 1:100000, list Prijepolje K34-16 [Basic geological map of SFRY 1:100000, Prijepolje sheet - in Serbian].1 Savezni geološki zavod, Beograd.

Ćurguz, Z., Stojanovska, Z., Žunić, Z. S., Kolarž, P., Ischikawa, T., Omori, Y., Mishra, R., Sapra, B. K., Vaupotič, J., Ujić, P., Bossew, P., 2015. Longterm measurements of radon, thoron and their airborne progeny in 25 schools in Republic of Srpska. J. Environ. Radioact. 148, 163-169.

EC, 2014. European Council: Council Directive 2013/59/Euratom of 5 December 2013 laying down basic safety standards for protection against the dangers arising from exposure to ionising radiation. Official J. Eur. Union 57 (L13), 1-73.

Ivanova, K., Stojanovska, Z., Tsenova M., Badulin, V., Kunovska, B., 2014. Measurement of indoor radon concentration in kindergartens in Sofia, Bulgaria. Radiat. Prot. Dosim. 162, 1-2, 163-166.

Ivanova, K., Stojanovska, Z., Tsenova, M., Kunovska, B., 2017. Building-specific factors affecting indoor radon concentration variations in different regions in Bulgaria. Air Qual. Atmos. Health. 10, 9, 1151-1161.

Kropat, G., Bochud, F., Jaboyedoff, M., Laedermann, J. P., Murith, C., Palacios Gruson, M., Baechler, S., 2015. Predictive analysis and mapping of indoor radon concentrations in estimation: a complex environment using kernel an application to Switzerland. Sci. Tot. Environ. 505, 137-148.

Mojsilović, S, Baklaić, D. Đoković, I., 1978. Osnovna geološka karta SFRJ 1:100000, list Sjenica K34-29 [Basic geological map of SFRY 1:100000, Sjenica sheet - in Serbian]. Savezni geološki zavod, Beograd.

Mojsilović, S, Baklaić, D. Đoković, I., 1980. Osnovna geološka karta SFRJ 1:100000. Tumač za list Sjenica K34-29 [Basic geological map of SFRY 1:100000, Geology of the Sjenica sheet - in Serbian]. Savezni geološki zavod, Beograd, $46 \mathrm{p}$.

Nikolopoulos, D., Kottou, S., Louizi, A., Petraki, E., Vogiannis, .Yannakopoulos, P. H., 2014. Factors affecting indoor radon concentrations of Greek dwellings through multivariate statistics. J. Phys. Chem. Biophys. 4, 145-150.

Sikošek, B., 1971. Tumač geološke karte SFR Jugoslavije, 1: 500000 [Explanation for Geological map of Yugoslavia, scale 1: 500000 - in Serbo-Croatian]. Savezni geološki zavod, Beograd, 62.

Stojanovska, Z., Boev, B., Zunic, Z. S., Ivanova, K., Ristova, M., Tsenova, M., Ajka, S., Janevik, E., 
Taleski, V. \& Bossew, P. 2016. Variation of indoor radon concentration and ambient dose equivalent rate in different outdoor and indoor environments. Radiat. Environ. Biophys. 55, 2, 171-183.

Stojanovska, Z., Stojanovska Z. A., Zunic, Z. S., Bossew P.,Bochicchio F., Carpentieri, C., Venoso, G., Mishra R., Rout, R. P., Sapra B, K., Burghele, B. D, Cucos-Dinu A, Boev, B. \& Cosma, C., 2014. Results from time integrated measurements of indoor radon, thoron and their decay product concentrations in schools in the Republic of Macedonia. Radiat. Prot. Dosim. 162, 1-2, 152-156.

Stojanovska, Z., Boev, B., Zunic, Z. S., Bossew, P., Jovevska, S., 2016. Results of radon CR-39 detectors exposed in schools due two different long-term periods. Nukleonika, 61, 3, 385-389.

Šabić D., Pavlović M., 2004. Climate characteristics of the Sjenica's region, Bulletin of the Serbian Geographical Society, 84, 2, 37-43.

Vaupotic, J, Krizman, M., Sutej, T., Peternel, M., Djuric G., Popovic, D., Planinic, J., Faj, Z., Kljajic, R., Stegnar, P., Kobal, I., 1992. Indoor radon concentrations in kindergartens from different regions of Yugoslavia. Radiat. Prot. Dosim. 45, 1-4 suppl.

Vaupotic, J., Szymula, M., Solecki, J., Chibowski, S., Kobal, I., 1993. Preliminary indoor radon investigations in Lublin region, Poland. Health Phys. 64, 4, 420-422.

Vaupotic, J., Sikovec, M., Kobal, I., 2000. Systematic indoor radon and gamma-ray measurements in Slovenian schools. Health Phys. 78, 5, 559-62.

Veselinović, V., Vuković, Lj., 1970. Geološkakarta SFR Jugoslavije, 1: 500000 [Geological map SFR Yugoslavia, scale 1: 500000 - in Serbo-Croatian]. Institut za geološko-rudarska istraživanja i ispitivanja nuklearnih i drugih mineralnih sirovina, Beograd.

Vuchkov, D., Ivanova, K., Stojanovska, Z., Kunovska, B., Badulin, B., 2013. Radon measurement in schools and kindergartens of Kremikovtsi municipality, Bulgaria. Rom. Rep. Phys. 58(S), 328-335.

WHO, 2009. Who Handbook on Indoor Radon - A Public Health Perspective. World Health Organization,

Yarmoshenko, I., Vasilyev, A., Malinovsky, G., Bossew, P., Žunić, Z. S., Onischenko, A. \& Zhukovsky, M., 2016. Variance of indoor radon concentration: Major influencing factors. Sci. Total Environ. 541, 155-160.

Živaljević, M., Mirković, M., Stijović, V., 1984. Osnovna geološka karta SFRJ 1:100000. Tumač za list Bijelo Polje K34-28 [Basic geological map of SFRY 1:100000, Geology of the Bijelo Polje sheet - in Serbian]. Savezni geološki zavod, Beograd, 56 p.

Živaljević, M., Mirković, M., Ćirić, A., 1983. Osnovna geološka karta SFRJ 1:100000, list Bijelo Polje K34-28 [Basic geological map of SFRY 1:100000, Bijelo Polje sheet - in
Serbian]. Savezni geološki zavod, Beograd.

Žunić, Z. S., Bossew, P., Bochicchio, F., Veselinovic, N. C., Carpentieri, C., Venoso, G., Antignani, S., Simovic, R. D., Curguz, Z., Udovicic, |V. I., Stojanovska, Z. \& Tollefsen, T., 2017a. The relation between radon in schools and in dwellings: A case study in a rural region of Southern Serbia. J. Environ. Radioact. 167, 188-200.

Žunić, Z. S., Stojanovska, Z., Veselinovic, N. C., Mishra, R., Yarmoshenko, I. V., Sapra, B. K., Ishikawa,T., Omori, Y., Curguz, Z., Bossew, P., Udovicic, V. I. \& Ramola ,R. C., 2017b. Indoor radon, thoron and their progeny concentrations in high thoron rural Serbia environments. Radiat. Prot. Dosim. 177, 1-2, 36-39.

Žunić, Z. S., Ujic, P. N., Nadderd, L. J., Yarmoshenko, I. V., Radanovic, S. B., Komatina-Petrovic, S., Celikovic I. T., Komatina, M. S. \& Bossew, P., 2014. High variability of indoor radon concentrations in uraniferous bedrock areas in the Balkan region. Appl. Radiat. Isot. 94, 328-337.

Žunić, Z. S. Carpentieri, C., Stojanovska, Z., Antignani, S., Veselinovic, N., Tollefsen, T., Carelli, V., Cordedda, C., Cuknic, O., Filipovic, J., Bossew, P. \& Bochicchio, F., 2013. Some results of a radon survey in 207 Serbian schools. Rom. Rep. Phys. 58(S), 320-327.

Žunić, Z. S., 2010. Identification and assessment of high radon areas in some rural regions of the Balkans, Doctoral Dissertation. Jožef Stefan, International Postgraduate School Ljubljana, Slovenia (in English)

Žunić, Z. S., Yarmoshenko, I. V., Veselinovic, N., Zhukovsky, M. V., Ujic, P., Celikovic, I., Mc Laughlin, J. P., Simopoulos, S. E., Birovljev, A., Fujimoto, K., Paridaens, J., Trotti, F., Tokonami, S., Olko, P., Kozak, K., Bochicchio, F., Ramola, R. C., Mietelski, J. W., Jakupi, B., Milic, G., Ciotoli, G., Kelleher, K., Budzanowski, M., Sahoo, S.K., Vanmarcke, H. \& Waligorski, M. P. R., 2009. Identification and assessment of elevated exposure to natural radiation in Balkan region (Serbia). Radioprotection, 44, 5, 919-925.

Žunic, Z. S., Yarmoshenko, I. V., Birovljev, A., Bochicchio, F., Quarto, M., Obryk, B., Paszkowski, M., Čeliković, I., Demajo, A., Ujić, P., Budzanowski, M., Olko, P., McLaughlin J.P. \& Waligorski, M. P. R., 2007. Radon survey in the high natural radiation region of Niška Banja, Serbia. J. Environ. Radioact. 92(3), 165-174.

Žunic, Z. S., McLaughlin, J.P., Walsh, C., Birovljev, A., Simopoulos, S. E, Jakupi, B., Gordanic, V., Demajo, M., Trotti, F., Falk, R. Vanmarcke, H., Paridaens, J. \& Fujimoto, K., 2001. Integrated Natural Radiation Exposure Studies In Stable Yugoslav Rural Communities. Sci. Total. Environ. 272, 253-259.

Received at: 09. 07. 2018

Revised at: 19. 11. 2018

Accepted for publication at: 23. 11. 2018

Published online at: 29. 11. 2018 